\title{
Determining Priority Service of Yogyakarta Adisutjipto Airport Using Servqual Method and Kano Model
}

\author{
Mikael Gabra Gani, Dewanti, Muhammad Zudhy Irawan, Faza Fawzan Bastarianto
}

Department of Civil and Environmental Engineering Universitas Gadjah Mada, Yogyakarta, INDONESIA

${ }^{*}$ Corresponding mikael.gabra.g@mail.ugm.ac.id

SUBMITTED 24 April 2019 REVISED 7 May 2019 ACCEPTED 6 September 2019

\begin{abstract}
Nowadays, airports are expected to be operated as a self-service organisation that provides efficient and high-quality services. Since the satisfaction of passengers is essential for airport's operators, the efforts to provide better services for passengers become a concern for airport's operators by increasing the quality of service to passengers. It is crucial to identify which kind of services that would be the top priority service for the passengers. Thus, this study aims to improve the quality of service to passengers that are conducted by combining the Servqual method and Kano model. Servqual method is used to capture consumer perceptions and expectations of service along with the multi-dimensional research instrument, while the Kano model is a theory to observe costumer's satisfaction preferences. The combination of the methods aims to determine the type of service that becomes the top priority for immediate improvement so that it can improve the service quality effectively. The selection of the priority services is based on the magnitude of the gap between expectations and perceptions of passengers on a particular service, and the assessment of passengers on the type of service that significantly influences passengers' satisfaction with the service performance at the airport. The results of this research showed that there were three types of services as the top priority for improving their performance, namely the type of services related to the personal attention to passengers, the attractive waiting room conditions, and the understanding of each passenger's needs individually. The airport management is expected to immediately improve the performance of the services so that the quality of service can immediately increase.
\end{abstract}

KEYWORDS Airport; Service Quality; Consumer Satisfaction; Servqual Method; Kano Model

(c) The Author(s) 2018. This article is distributed under a Creative Commons Attribution-ShareAlike 4.0 International license.

\section{1}

\section{INTRODUCTION}

Yogyakarta Adisutjipto Airport is the most important national and international tourist gateway for tourist areas in several regions such as Yogyakarta, Solo, Semarang, and several other Central Java regions. With a reasonably extensive service area, Yogyakarta Adisucipto Airport certainly has a high enough annual passengers volume in line with the development of tourism that is also rapidly increasing. The increase in the number of passengers that occurred annually resulted in the volume of passengers served exceeding the capacity of both the airside and the land side. According to Sugianto (2019), the passengers capacity of the Yogyakarta Adisucipto Airport plan is 1.7 million passengers per year, while the number of passengers in 2017 was 6,410,668 people (PT. Angkasa Pura I, 2017), and in 2018 (up to November) there were 6,374,233 people (PT. Angkasa Pura I, 2018). It means that Adisutjipto Airport has a passengers volume of almost four times the airport capacity that it should be.

The condition of Yogyakarta Adisucipto Airport that exceeds the infrastructure capacity of this plan greatly affects the quality of service received by airport service users, both passengers and airlines. The availability of service facilities, as well as operational officers who are not able to keep up with the existing passenger's volume, will affect the quality of services to be provided. It happens because the availability of service facilities and airport operational staff is ys adjusted to the passengers capacity of an airport plan. Therefore it is very important to make various efforts to anticipate the low quality of services provided to passengers, due to the excess capacity that occurs at Yogyakarta Adisucipto Airport. According to Bezerra \& Gomes (2016), when there is an increase in the number of passengers at an airport, the critical thing to do is to optimise the infrastructure performance, and 
always focus on efforts that are oriented to the availability of quality services desired by passengers. It is done so that the effect of passengers density at an airport is not felt too much by passengers; thus, the passengers' comfort is maintained in all conditions.

Therefore, this research aims to improve the quality of service to passengers that are conducted by combining the Servqual method and Kano model. The combination of the methods will determine the type of service that becomes the top priority for immediate improvement so that it can improve the service quality effectively.

\section{LITERATURE REVIEW}

\subsection{Passengers Terminal}

The terminal area is the link between the airside and the whole of anything of an airport (Horonjeff et al., 2010). The terminal area is a facility for passengers and baggage processing, cargo handling, as well as maintenance, operational, and administrative activities for an airport. The system on the passengers terminal has three main components where the function is carried out by several available facilities, namely the access interface, processing, and flight interface (Sartono, Dewanti, \& Rahman, 2016).

According to Innayah (2017), the principle of passengers terminal design should be based on the needs of various airport users such as passengers, flights, airport management, and environmental communities around the airport. From the passengers perspective, the terminal design principle must prioritise a rapid response to needs related to convenience, comfort, and personal needs. On the other point of view, which is the airline companies, the design must consider the existing fleet, and that will exist in the future with maximum operational efficiency. In terms of airport management, the terminal design must consider the maintenance side of the existing terminal operations, access systems, runway systems, and supporting facilities during the construction period. According to community's opinion, the design must consider the statements and impressions of the community that are unique and feasible.

\subsection{Airport's Service Quality}

The development of air transportation activities throughout the world has increased the demand for airport services, and the need for more efficient processes in serving aircraft, passengers, or items of baggage. All airlines seek and expand their operations at airports that operate efficiently to reduce costs and improve the quality of services provided to passengers (Pabedinskaite and Akstinaitè, 2014). The quality of services provided by airports is very important for consumers who use airport services. Consumers must feel comfortable with the services provided by the airport so that the image of the airport will be good in the eyes of consumers (Darus, 2015).

According to Muda (2014), the assessment of the service quality of an airport highly depends on the assessment of all parties using the airport services, both airlines and passengers. The airlines and passengers have different indicators in providing an assessment of the quality of services provided by an airport. Passengers assess the satisfaction of airport service quality by looking at each type of services in the airport. (Subekti, 2018).

Kurniawan et al., (2017) investigated the passengers' satisfaction toward people mover facility service quality in Grand Design of Soekarno Hatta International Airport (SHIA). The service quality is measured by Serqual method and the Kano model approach. The study found that the passengers' satisfaction is significantly influenced by six attributes which are punctuality, free of charge, information about the schedule, headway, and safety. The airport management at SHIA should fill that value gap by improving those service attributes to meet passengers' satisfaction.

\subsection{Service Quality of Yogyakarta Adisutjipto Airport}

The service quality at Yogyakarta Adisucipto Airport changes over time as the air transport grows. The growth of air transportation refers to the growth in the number of airport service users 
that increase every year. According to Santosa (2007), the conditions of the waiting room facilities of the Yogyakarta Adisucipto Airport terminal are adequate. It can be seen in the high level of the service satisfaction of the Adisutjipto Airport service users. Based on the customer satisfaction index analysis (CSI) conducted on the service users of Yogyakarta Adisutjipto Airport, it is found that $61 \%$ passengers feel "very satisfied" with the airport's waiting room facilities, the remaining $18 \%$ passengers think "satisfied", and the remaining only $21 \%$ passengers who feel "dissatisfied". It shows that the facilities provided in the waiting room of the Yogyakarta Adisucipto Airport terminal already meet the passengers' expectations.

According to Sri Mulyani \& Dwi Hartini (2016), the occurrence of delayed arrival at Yogyakarta Adisutjipto Airpor during the flight peak hours is caused by the inadequate parking stand capacity. The number of parking booths that are not following the movement of the aircraft at the peak hours causes a flight queue when landing with a long duration. In addition to the parking stand capacity problem, the ownership status of the airport as a civil enclave also greatly affected the occurrence of aircraft queues when taking take-off and landing processes. Therefore, Sri Mulyani \& Dwi Hartini (2016) considered that Yogyakarta should have a special airport for commercial purposes that is separated from military interests so that the flight activities are more effective, and can reduce the late arrival factor caused by late landing.

According to Subekti (2018), not all types of services at the Yogyakarta Adisucipto Airport have maximum performance. Based on passenger perceptions of the 19 types of services available at Yogyakarta Adisutjipto Airport, there are six types of services whose performance is relatively not satisfying passengers. The six types of services include the availability of free drinking water facilities, cleanliness and comfort of children's playroom facilities, availability of facilities for users with special needs, availability of internet facilities, cleanliness and comfort of breastfeeding rooms, and cleanliness of smoking rooms. Subekti (2018) considers that the six types of services above still need attention to improve their performance to increase the positive perception of passengers.

The efforts to improve service quality are crucial things to do at each airport, including at Yogyakarta Adisutjipto Airport. The efforts to improve the service quality are one form of the airport management's commitment to serving the highest quality passengers. One effort to improve the service quality is by increasing the capacity in which by reducing the service time. Innayah (2017) provides alternative recommendations for the design simulation model of the departure passengers queue at Terminal A Yogyakarta Adisucipto Airport to reduce the queue duration due to the ticket checks, security checks, and check-in processes; thus the terminal capacity will be increased.

\section{THEORETICAL REVIEW \\ 3.1 Servqual Method}

Servqual method is a method commonly used in measuring the service quality of a company. The Servqual method identifies the service quality by calculating the gap between the customer's perception of service that is actually received with the service that customers actually expect (Yousapronpaiboon, 2014). If the service that is received by customers is equal or more than expected, then it can be said that the quality of the service is classified as good. But conversely, if the service that is received by customers is less than what is expected, then it can be said that the quality of the service is bad (Zeithaml, Berry and Parasuraman, 2006).

In addition to measuring the gap between the customer's perception and expectation, the Servqual method also measures the difference that Setiawan (2018) refers to as internal gaps or gaps that occur within the service provider structure. The internal gap consists of Gap 1 - the gap between the customer's expectation and the management perception of customer expectation. Gap 2 - The gap between the management perception of the customer's 
expectation with the specification and standardisation of the service quality determined by the company management. Gap 3 - The gap between the specification and standardisation of the services that have been determined by the management with service delivery by the employees. Gap 4 - The gap between the service delivered by the employees and the services that have been informed to the external parties. The gap between the customer's expectation and the customer's perception of a service is defined as Gap 5.

Parasuraman, Zeithaml, \& Berry (1988) describe the Servqual method into five main dimensions, namely tangible, responsiveness, assurance, empathy, and reliability. The five main dimensions of the Servqual method are explained as follows:

1. Tangibles are the ability of a company to show its existence to external parties through physical facilities, equipment, technology, employee appearance, and means of communication.

2. Responsiveness is the ability of a company to provide prompt and immediate service to customers.

3. Empathy includes the ease of relationship, good communication, personal attention, and understanding customer needs.

4. Assurance is a service provided with the basis of knowledge, competence, politeness, and the trustworthy nature of employees in the task of providing services to customers, so that they are free from danger, risk, or doubt.

5. Reliability is the ability of a service that is presented accurately, satisfactorily, and reliably. Reliability includes two main things, the first is the consistency of work, and the second is the ability to be trusted.

According to Al-alak, Salih, \& Alnaser (2012), of the five main dimensions that exist, tangible is the dimension most often used in evaluating the customer's perception and expectation of the service quality. Tangible is considered more representative in explaining the quality of service and it is easier to assess because it is physical and public.

\subsection{Kano Model}

Kano model was developed by Professor Noriaki from Tokkyo Rika University and it aims to categorise the service attributes based on how well the service is able to provide satisfaction to consumer needs (Herbowo, 2018). The Kano model is used to study each of the nature of the customer needs, providing a way to the better classify customer needs (Ma, Chen and Chang, 2019). According to Kano (1984), each customer has a different attitude towards different service attributes, this is due to the different level of needs of each customer for the existing services, depending on the customer's background. The Kano model is divided into six categories based on the characteristics of the service to the level of the customer's satisfaction, namely: must be, one dimensional, attractive, indifferent, reserve, and questionable (Yao, Chuang and Hsu, 2018). The six Kano categories are explained as follows:

1. Must be (M) illustrates that if the service performance provided by the service provider is bad, then the level of customers satisfaction will decrease. But the customer's satisfaction will not increase even though there is an increase in service performance.

2. The one dimensional illustrates that the service performance that is given is directly proportional (linear) with a level of satisfaction felt by the customers.

3. The attractive (A) provides an overview of the increase in the customer's satisfaction if the performance of the services provided improves, but the customer's satisfaction will not decrease even if there is a decrease in the performance of the services provided.

4. Indifferent (I) illustrates that the satisfaction felt by the customers is not affected by the service provided.

5. Reverse (R) illustrates that the service performance provided to the customers is inversely proportional to the level of the satisfaction felt by the customers.

6. Questionable (Q) describes the mismatch between the questions given in the 
questionnaire and the answers given by the respondents.

\section{RESEARCH METHOD}

\subsection{Questionnaire design}

The data collecting method used in this research is by distributing questionnaires to 400 passengers who are using the services of Yogyakarta Adisucipto Airport. The demographic data of the sample which also includes the annual frequency of airport utilisation is shown in Table 2 .

In this research, there are two types of questionnaires distributed to the passengers, namely the Servqual questionnaire, and the Kano questionnaire. The Servqual questionnaire consists of 20 types of questions divided into five main dimensions of Servqual namely reliability (4 questions), assurance (4 questions), tangible (4 questions), responsiveness (4 questions), and empathy (4 questions). The Servqual questionnaire uses the Likert Scale in its assessment, which starts from strongly disagree (1) to strongly agree (5). Just like the Servqual questionnaire, the Kano questionnaire also consists of 20 types of questions (the same questions with the Servqual questionnaire), but each type of question is divided into two forms, namely functional forms (positive questions), and dysfunctional forms (negative questions). The Kano questionnaire uses rating scales from 1 to 5 with the following definitions 1 (likes), 2 (must be), 3 (neutral), 4 (live with), and 5 (dislike).

\subsection{Stages of Data Analysis}

1. The tests of the data validity and reliability are carried out on each data derived from the Servqual questionnaire and the Kano questionnaire. The test of the data validity aims to determine the accuracy of the interpretation made from the results of the data measurement or evaluation, and the reliability test of the data aims to determine the accuracy of the results obtained from a measurement (Gronlund \& Linn, 1990).

2. The service gap analysis is carried out by calculating the differences between the average value of the passengers' expectation and the average value of the passengers' perception of the services provided by both the operational employees and the airport management.

3. The Wilcoxon Signed Rank Test is conducted to find out whether there is a significant difference between the average value of the passengers' expectation and the average value of the passengers' perception, with the following hypothesis:

$\mathrm{Ho}=$ there is no difference between the average value of "passengers' expectation" and "passengers' perception".

$\mathrm{Ha}=$ there is a difference between the average value of "passengers' expectation" and "passengers' perception".

The basis for decision making is a) if the asymptotic significance value is $>0.5$, then Ho is accepted (there is no difference); $b$ ) if the asymptotic significance value is $<0.05$ then $\mathrm{Ha}$ is accepted (there is a difference).

4. The determination of 20 types of services (from 20 types of questions) at the airport into 6 Kano categories (attractive, one dimensional, must be, indifferent, reserve and questionable). The determination of the Kano category begins by dividing 1 type of service (question) into two forms, namely the functional form and the dysfunctional form, which then the Kano category is selected based on Table 1.

5. The determination of the extent of satisfaction (EOS) indicates how much percentage of the customers' satisfaction increases if a certain type of service is provided. The extent of dissatisfaction (EOD) indicates how much the percentage of the customers' satisfaction decreases if certain types of services are not provided.

6. The determination of priority coefficients by summing the value of Gap 5, EOS, and EOD, to determine the type of service that is the top priority in the improvement and development that are carried out at Yogyakarta Adisutjipto Airport. 
Table 1. Kano evaluation table

\begin{tabular}{|c|c|c|c|c|c|c|}
\hline \multirow{2}{*}{\multicolumn{2}{|c|}{ Customer Requirements }} & \multicolumn{5}{|c|}{ Dysfunctional (negative) question } \\
\hline & & \multirow{2}{*}{$\begin{array}{l}\begin{array}{l}1 . \\
\text { like }\end{array} \\
\end{array}$} & \multirow{2}{*}{$\begin{array}{r}\begin{array}{c}2 . \\
\text { must-be }\end{array} \\
\mathrm{A}\end{array}$} & \multirow{2}{*}{$\begin{array}{r}\begin{array}{c}3 . \\
\text { neutral }\end{array} \\
\mathrm{A}\end{array}$} & \multirow{2}{*}{$\begin{array}{r}\frac{4 .}{\text { live with }} \\
\text { A }\end{array}$} & \multirow{2}{*}{\begin{tabular}{r}
\multicolumn{1}{c}{$\begin{array}{l}5 . \\
\text { dislike }\end{array}$} \\
0
\end{tabular}} \\
\hline \multirow{5}{*}{$\begin{array}{l}\text { Functional (positive) } \\
\text { question }\end{array}$} & $\begin{array}{l}1 . \\
\text { like }\end{array}$ & & & & & \\
\hline & $\begin{array}{c}2 . \\
\text { must-be }\end{array}$ & $\mathrm{R}$ & I & $\mathrm{I}$ & I & M \\
\hline & $\begin{array}{c}3 . \\
\text { neutral }\end{array}$ & $\mathrm{R}$ & I & I & I & M \\
\hline & $\begin{array}{c}4 . \\
\text { live with }\end{array}$ & $\mathrm{R}$ & I & I & I & M \\
\hline & $\begin{array}{c}5 . \\
\text { dislike }\end{array}$ & $\mathrm{R}$ & $\mathrm{R}$ & $\mathrm{R}$ & $\mathrm{R}$ & Q \\
\hline
\end{tabular}

\section{RESULTS AND DISCUSSION}

\subsection{Profiles of the Respondents}

The selection of the respondents in this research is based on the frequency of the airport use in a year. The passengers, who are the respondents, are the passengers who have the frequency of the airport use at least two times a year. Furthermore, the respondents are also selected based on the productive age range. According to Subri (2003), the productive age is a group of people ranging in ages from 15 to 64 years old. The productive age is defined as the age at which people can produce goods or services because of the level of maturity of good thinking. Therefore the respondents in this research are the passengers in the age ranges of 15 to 64 years old.

Table 2. Demographic data of the sample $(N=400)$

\begin{tabular}{llcc}
\hline Variables & & $\mathrm{N}$ & $\%$ \\
\hline \multirow{2}{*}{ Gender } & Male & 219 & 54.75 \\
\cline { 2 - 4 } & Female & 181 & 45.25 \\
\hline \multirow{3}{*}{ Age } & $15-31$ Years & 227 & 56.75 \\
\cline { 2 - 4 } & $32-47$ Years & 122 & 30.50 \\
\cline { 2 - 4 } & $48-65$ Years & 51 & 12.75 \\
\hline $\begin{array}{l}\text { Annual frequency } \\
\text { airport utilization }\end{array}$ & $2-5$ Times & 239 & 59.75 \\
\cline { 2 - 4 } & $>5$ Times & 161 & 40.25
\end{tabular}

\subsection{Test Results of Data Validity}

The results of the data validity test on the Servqual questionnaire (passenger expectations passenger perceptions) and the Kano questionnaire (functional questions and dysfunctional questions) using SPSS software show that the calculated $r$-value is greater than the $r$ table value for 400 respondents (r-count > 0.098). Based on the calculated $r$-value, it is concluded that all data is valid.

\subsection{Test Results of Data Reliability}

The data reliability test results show that all data derived from the Servqual questionnaire (passenger expectations - passenger perceptions) and Kano questionnaire (functional questions dysfunctional questions) have a Cronbach's Alpha value greater than 0.7. The passengers' perception has the Cronbach's Alpha value of 0.94 , the passengers' expectation of 0.965 , the functional question of 0.916, and the dysfunctional question of 0.913 . Based on the value of Cronbach's Alpha above, it can be concluded that all data is reliable. 


\subsection{Service Gap Analysis (Gap 5)}

According to Parasuraman, Zeithaml, \& Berry (1985), the main benchmarks which are the basis for knowing how well the service quality that occurs in a service system is to know the gap that arises between customers' expectations and perceptions of the type of the service offered by the service providers (gap 5). In this research, the gap five is defined as the gap that occurs between the quality of service expected by the passengers and the perception of passengers on the service performance received while using the services of Yogyakarta Adisucipto Airport.

The expectations of passengers can be motivated by the promise of the service quality received in the form of advertising or promotion, or even related to the general standard of service that should occur at an airport with the status of an international airport. Whereas the passengers' perception is a form of subjective assessment that may be motivated by the experience of using other airports with the same class and type thus it can be compared with the airport studied, or can also be driven by the customers' dissatisfaction with the service problems that may occur during the service process at the airport. Table 3 shows data on average passengers' expectations, passengers' perceptions, gap scores, and the Wilcoxon test results.

The Wilcoxon Signed-Rank Test results show that the asymptotic significance value of the 20 types of services tested has a value of less than 0.05 . Therefore Ho is rejected, and Ha is accepted, which means that there is a significant difference between the average value of the passengers' perception and the passengers' expectations for the service at Yogyakarta Adisutjipto Airport.
From Table 3 above it can be seen that the average value of the passengers' perceptions is lower than the passengers' expectations, which means that the service performance at Yogyakarta Adisucipto Airport is not in line with the passengers' expectations. Therefore the passengers consider that the service performance at Adisutjipto Airport still needs improvement and development. In detail, the gap between perceptions and expectations of the passengers on the services available at Yogyakarta Adisucipto Airport can be explained as follows:

1. Tangible. In this dimension, the passengers assess the performance or the quality of service at the airport does not meet the passengers' expectations, where there is a gap score with a value of -0.994 between the perceptions and the expectations of the passengers. This gap score with a negative value indicates the passengers' dissatisfaction with the visual aspects of the waiting room. The visual condition of the waiting room is considered unattractive and boring. Of the several passenger's narratives related to this, one of the causes of the uninteresting waiting room is due to the absence of a clear boundary or partition between the spaces for existing gates. Although there are several gates in the waiting room, the lack of the division of space, based on the existing gate, makes the visual situation in the waiting room of Yogyakarta Adisutjipto Airport unattractive. This passengers' assessment can occur due to the experience of the passengers at several airports that have the same type and level as the Yogyakarta Adisucipto Airport, which has a visually attractive waiting room. 
Table 3. Result of service gap analysis

\begin{tabular}{|c|c|c|c|c|c|}
\hline Dimensions and Types of Services & $\begin{array}{l}\text { Passangers' } \\
\text { Perceptions } \\
\text { (P) } \\
\text { Mean }\end{array}$ & $\begin{array}{c}\text { Passangers' } \\
\text { Expectation } \\
\mathrm{S}(\mathrm{E}) \\
\text { Mean }\end{array}$ & $\begin{array}{l}\text { Service Gap } \\
\text { Score } \\
\text { (P-E) } \\
\text { Mean }\end{array}$ & Z Value & $\begin{array}{l}\text { Asymp. Sig. } \\
\text { (2-tailed) }\end{array}$ \\
\hline Tangible & 3.6456 & 4.5894 & -0.9438 & -15.7350 & 0.000 \\
\hline The airport has up-to-date equipments & 3.5900 & 4.5800 & -0.9900 & -14.8400 & 0.000 \\
\hline $\begin{array}{l}\text { The airport has an atractive waiting } \\
\text { room }\end{array}$ & 3.4425 & 4.5600 & -1.1175 & -14.6270 & 0.000 \\
\hline The airport looks clean & 3.7525 & 4.6475 & -0.8950 & -14.5900 & 0.000 \\
\hline $\begin{array}{l}\text { The airport employees are well dressed } \\
\text { and appear neat }\end{array}$ & 3.7975 & 4.5700 & -0.7725 & -13.3670 & 0.000 \\
\hline Responsible & 3.8581 & 4.6938 & -0.8356 & -15.2760 & 0.000 \\
\hline $\begin{array}{l}\text { Passengers complaints are handled } \\
\text { quickly }\end{array}$ & 3.8025 & 4.6625 & -0.8600 & -13.9220 & 0.000 \\
\hline $\begin{array}{l}\text { The airport employees inform service } \\
\text { quickly }\end{array}$ & 3.9375 & 4.7000 & -0.7625 & -13.3320 & 0.000 \\
\hline $\begin{array}{l}\text { The airport employees are ready when } \\
\text { needed }\end{array}$ & 3.9000 & 4.7075 & -0.8075 & -13.6360 & 0.000 \\
\hline $\begin{array}{l}\text { The airport employees offer fast } \\
\text { service }\end{array}$ & 3.7925 & 4.7050 & -0.9125 & -14.5900 & 0.000 \\
\hline Emphaty & 3.7341 & 4.6669 & -0.9327 & -15.8590 & 0.000 \\
\hline $\begin{array}{l}\text { The airport employees give personal } \\
\text { attention to every passenger }\end{array}$ & 3.6115 & 4.6550 & -1.0435 & -14.3630 & 0.000 \\
\hline The airport employees serve fairly & 3.7975 & 4.6900 & -0.8925 & -14.6190 & 0.000 \\
\hline $\begin{array}{l}\text { The airport employees understand } \\
\text { passengers need specifically }\end{array}$ & 3.6500 & 4.6300 & -0.9800 & -14.5040 & 0.000 \\
\hline $\begin{array}{l}\text { The airport employees apologized } \\
\text { when making a mistake }\end{array}$ & 3.8775 & 4.6925 & -0.8150 & -14.1300 & 0.000 \\
\hline Assurance & 3.9219 & 4.6963 & -0.7744 & -14.9270 & 0.000 \\
\hline $\begin{array}{l}\text { Passengers trust to the airport } \\
\text { employees }\end{array}$ & 3.8325 & 4.6675 & -0.8350 & -14.0040 & 0.000 \\
\hline $\begin{array}{l}\text { The airport employees are polite to } \\
\text { passengers consistently }\end{array}$ & 3.9350 & 4.7225 & -0.7875 & -14.0210 & 0.000 \\
\hline $\begin{array}{l}\text { The airport employees have the } \\
\text { competence to do their job }\end{array}$ & 3.9475 & 4.6925 & -0.7450 & -13.8700 & 0.000 \\
\hline $\begin{array}{l}\text { Passengers feel safe in their } \\
\text { transactions with the airport } \\
\text { employees }\end{array}$ & 3.9725 & 4.7025 & -0.7300 & -13.4200 & 0.000 \\
\hline Reliability & 3.9088 & 4.6925 & -0.7837 & -14.2560 & 0.000 \\
\hline The service process run on time & 3.7975 & 4.6850 & -0.8875 & -13.5990 & 0.000 \\
\hline $\begin{array}{l}\text { The airport employees provide } \\
\text { information accurately }\end{array}$ & 3.8875 & 4.7125 & -0.8250 & -13.6170 & 0.000 \\
\hline The airport employees serve seriously & 4.0050 & 4.6725 & -0.6675 & -12.7260 & 0.000 \\
\hline $\begin{array}{l}\text { Sevice is carried out properly since } \\
\text { first time }\end{array}$ & 3.9450 & 4.7000 & -0.7550 & -13.2900 & 0.000 \\
\hline
\end{tabular}


In addition to the visual aspects of the waiting room, the assessment of the modern and adequate physical facilities is also a concern of the passengers. Based on the observations during conducting the research, and also from several inputs during filling in questionnaires by the passengers, it is found, that the physical facilities such as broken chairs and electrical sockets are facilities that the passengers complain most. The last aspect, which is considered to have unsatisfactory performance is related to the cleanliness of the airport environment, whereas the passengers and visitors are found not using the smoking area facilities for smoking. So that it causes air pollution and a lot of cigarette waste are scattered all over the airport area.

2. Responsiveness. In this dimension, there is a gap score with a value of -0.836 , which indicates that Yogyakarta Adisucipto Airport has not been able to provide the fast and the prompt service based on the passengers' expectations. In general, the passengers expect a short time in each service process whether it is providing information, handling complaints, or preparing airport staff to assist the passengers who experience problems within the terminal. Services that are carried out quickly can increase the terminal capacity (Innayah, 2017). However, the results of the study show that at Yogyakarta Adisutjipto Airport, there are still long queues at the check-in area which make the passengers need to take a long time to get serviced. The queue at the check-in area can be caused by the volume of passengers that have exceeded the existing terminal capacity, or caused by the low performance of the airport operational staff in providing the prompt service.
3. Empathy. In this dimension, a gap score of 0.933 is obtained which indicates the performance of operational employees in giving personal attention to the passengers has not run optimally. Furthermore, the passengers also consider that the operational employees are less able to understand the passengers' desires specifically, so that meeting passenger need is considered to be less than optimal.

4. Assurance. This dimension includes the certainty of security during the service process, both for the personal passengers and for the passengers' items of luggage. Of the five dimensions, the guarantee dimension is the dimension that has the smallest gap score. However, the gap score with negative values on this dimension still indicates that passengers' expectations for security, calmness and comfort, in both personal and items of luggage, have not been maximally fulfilled, therefore it still needs to be improved in performance.

5. Reliability. This dimension includes the passengers' trust in the ability/reliability of services provided by Yogyakarta Adisucipto Airport. In this dimension, the passengers assess the service information that has been provided, sometimes does not take place on time, so that the level of trust in the information provided by the airport is reduced. The accuracy of the information provided by the airport is still considered not optimal by the passengers. It indicates the competency of the airport (operational and management staff) in estimating time and information is still not optimal. 


\subsection{Kano Model Analysis}

After analysing using the Servqual method, the next process is to investigate the twenty types of services available at Yogyakarta Adisutjipto Airport using the Kano model. In the analysis using the Kano model there are several stages to be carried out, starting with determining each type of service into 6 Kano categories (attractive, one dimensional, indifferent, reserve, questionable), then calculating the Kano satisfaction coefficient values ( extent of satisfaction and extent of dissatisfaction) to determine the effect of each type of service on the level of passengers' satisfaction. The results of the analysis using the Kano model can be seen in Table 4 below.

The results of the analysis using the Kano model show that there are 17 types of services that fall into the category of must be $(\mathrm{M}), 2$ types of services that fall into the one dimensional $(\mathrm{O})$ category, and only 1 type of service that falls into the attractive category (A ). Meanwhile, there are no types of services that fall into Indifferent (I), reserve $(\mathrm{R})$ and questionable $(\mathrm{Q})$ categories.

The seventeen types of services included in the must be category illustrate that this type of service only affects the decrease in the passengers' satisfaction, and does not affect the increase in the passengers' satisfaction. It is because when the type of service in the must-be category experiences a decline in the performance, it will affect the decrease in the passengers' satisfaction, but the passengers' satisfaction will not increase even though the service performance has increased.
Then the types of services included in the attractive category illustrate that if the service performance is improved, it will affect the increase in the passengers' satisfaction. But conversely, if the type of service performance decreases, it will not affect the decrease in the passengers' satisfaction. This category only affects the increase in satisfaction and not vice versa. This category is inversely proportional to the category of must be. While the two types of services included in the one-dimensional category illustrate that passenger satisfaction is strongly affected by the performance of each type of service available. The passengers' satisfaction level will increase when the service type performance increases and the passengers' satisfaction level decrease when the service type performance decreases.

Of the twenty types of services available at Yogyakarta Adisutjipto Airport, the attractive waiting room services, the personal attention paid to the passengers, and the officers' understanding for the passengers' needs specifically, are the types of the services that mostly influence the increase in the passengers' satisfaction at Yogyakarta Adisutjipto Airport. It can be seen from the extent of satisfaction (EOS) of the three types of services that have the greatest value among other types of services. Three services that have the greatest influence on reducing the passengers' satisfaction, they are the accuracy of the information, the services are carried out correctly and precisely and the fairness of the officers. It can be seen from the value of the extent of dissatisfaction (EOD) of the three types of services above having the greatest value compared to other types of services. 
Table 4. Result of Kano analysis

\begin{tabular}{|c|c|c|c|c|c|c|c|c|c|}
\hline \multirow{2}{*}{ Types of Services } & \multicolumn{6}{|c|}{ Category of Kano } & \multirow{2}{*}{$\begin{array}{l}\text { Selected } \\
\text { Category }\end{array}$} & \multirow{2}{*}{ EOS } & \multirow{2}{*}{ EOD } \\
\hline & A & $\mathrm{O}$ & M & $\mathrm{R}$ & I & $Q$ & & & \\
\hline The airport has up-to-date equipments & 72 & 83 & 120 & 1 & 123 & 1 & M & 0.3894 & -0.5101 \\
\hline $\begin{array}{l}\text { The airport has an atractive waiting } \\
\text { room }\end{array}$ & 133 & 97 & 69 & 1 & 97 & 3 & $\mathrm{~A}$ & 0.5808 & -0.4192 \\
\hline The airport looks clean & 26 & 138 & 178 & 2 & 48 & 4 & M & 0.3451 & -0.6270 \\
\hline $\begin{array}{l}\text { The airport employees are well dressed } \\
\text { and appear neat }\end{array}$ & 48 & 115 & 165 & 1 & 69 & 2 & $\mathrm{M}$ & 0.4106 & -0.7053 \\
\hline $\begin{array}{l}\text { Passengers complaints are handled } \\
\text { quickly }\end{array}$ & 31 & 103 & 189 & 0 & 75 & 2 & $\mathrm{M}$ & 0.3367 & -0.7337 \\
\hline $\begin{array}{l}\text { The airport employees inform service } \\
\text { quickly }\end{array}$ & 48 & 109 & 173 & 1 & 66 & 3 & M & 0.3965 & -0.7121 \\
\hline $\begin{array}{l}\text { The airport employees are ready when } \\
\text { needed }\end{array}$ & 26 & 121 & 172 & 0 & 78 & 3 & M & 0.3703 & -0.7380 \\
\hline The airport employees offer fast service & 53 & 135 & 135 & 0 & 75 & 2 & M & 0.4724 & -0.6784 \\
\hline $\begin{array}{l}\text { The airport employees give personal } \\
\text { attention to every passenger }\end{array}$ & 75 & 136 & 82 & 4 & 99 & 4 & $\mathrm{O}$ & 0.5383 & -0.5561 \\
\hline The airport employees serve fairly & 19 & 124 & 190 & 1 & 64 & 2 & $\mathrm{M}$ & 0.3602 & -0.7909 \\
\hline $\begin{array}{l}\text { The airport employees understand } \\
\text { passengers need specificaly }\end{array}$ & 64 & 138 & 99 & 0 & 97 & 2 & $\mathrm{O}$ & 0.5075 & -0.5955 \\
\hline $\begin{array}{l}\text { The airport employees apologized } \\
\text { when making a mistake }\end{array}$ & 33 & 136 & 172 & 0 & 57 & 2 & M & 0.4246 & -0.7739 \\
\hline $\begin{array}{l}\text { Passengers trust to the airport } \\
\text { employees }\end{array}$ & 43 & 131 & 164 & 0 & 60 & 2 & M & 0.4372 & -0.7412 \\
\hline $\begin{array}{l}\text { The airport employees are polite to } \\
\text { passengers consistently }\end{array}$ & 33 & 111 & 185 & 1 & 68 & 2 & $\mathrm{M}$ & 0.3627 & -0.7456 \\
\hline $\begin{array}{l}\text { The airport employees have } \\
\text { competence to do their job }\end{array}$ & 28 & 84 & 214 & 0 & 72 & 2 & $\mathrm{M}$ & 0.2814 & -0.7487 \\
\hline $\begin{array}{l}\text { Passengers feel safe in their } \\
\text { transactions with the airport } \\
\text { employees }\end{array}$ & 33 & 126 & 175 & 3 & 59 & 4 & M & 0.4046 & -0.7659 \\
\hline The service process run on time & 23 & 114 & 194 & 0 & 67 & 3 & $\mathrm{M}$ & 0.3442 & -0.7739 \\
\hline $\begin{array}{l}\text { The airport employees provide } \\
\text { information accurately }\end{array}$ & 22 & 108 & 216 & 0 & 52 & 3 & $\mathrm{M}$ & 0.3266 & -0.8141 \\
\hline The airport employees serve seriously & 26 & 107 & 200 & 0 & 62 & 5 & M & 0.3367 & -0.7772 \\
\hline $\begin{array}{l}\text { Sevice is carried out properly since first } \\
\text { time }\end{array}$ & 19 & 111 & 209 & 0 & 58 & 3 & M & 0.3275 & -0.8060 \\
\hline
\end{tabular}

\subsection{Integration of Servqual Model and Kano Model}

Based on the service gap analysis using the Servqual method that has been done before, it is found that there are still gaps with very significant values between the service quality expected by the passengers, and the service quality that is truly felt (passengers' perceptions) at Yogyakarta Adisutjipto Airport. Then based on the analysis using the Kano model on the twenty types of services available at Yogyakarta Adisutjipto Airport, there are three types of services that have the most influence on increasing the passengers' satisfaction, and the three types of services that have the most impact on reducing the passengers' satisfaction. So at this stage, a joint analysis will be carried out by integrating the Servqual analysis with the Kano model analysis, by considering three criteria in 
each type of service, namely the gap value, the extent of satisfaction (EOS), and the extent of dissatisfaction (EOD). To determine the type of service that becomes the top priority in improving and developing the performance to increase the quality of the existing services at Yogyakarta Adisutjipto Airport.

In this integration model, the basis for selecting the priority service types is by paying attention to the combination of the service gap values, the extent of satisfaction, and the extent of dissatisfaction. Based on the service gap value, the type of service that becomes the top priority in improving and developing the performance is the type of service that has the greatest gap value. Because the greater the gap value indicates the type of service is at the worst performance. Based on the value of extent of satisfaction and extent of dissatisfaction, the type of service that has the greatest influence both in increasing satisfaction and decreasing passengers' satisfaction is a type of service that must be considered more than other types of services. So that in the integration of Servqual and Kano models, the type of service with the combination of gap scores, the extent of satisfaction, and the extent of dissatisfaction, will be the highest priority compared to the type of service with the value below. From table 5, it can be seen that the types of services that become the top priority for improvement and performance improvement at Yogyakarta Adisutjitpo Airport are the personal attention of the airport operations employees to the passengers. The improvements to the performance of this type of service are very important to do, because of the results of the Servqual analysis of this type of service find a gap with a significant value between the passengers' expectations and the services experienced by the passengers. This significant gap illustrates the service performance that is far from the passengers' expectations, so it is highly recommended to be improved. Besides being caused by a significant gap, this type of service is also considered to be able to increase passenger satisfaction because this type of service is included in the one dimensional $(\mathrm{O})$ category, which means that if the performance is improved, it will affect the increase in the passengers' satisfaction.

The second type of service that becomes a priority for improvement and performance improvement is the attractive waiting room. The aesthetic aspect of the waiting room is considered far from the expectations of the passengers, as evidenced by the finding of the gap with the greatest value from other types of services. Besides having the biggest gap value, this type of service is also considered to have the most considerable influence on increasing the passengers' satisfaction if the performance is maximum. Therefore it is essential to improve its performance. The aesthetic aspect of the waiting room is a type of service that falls into the attractive (A) category, which means that if this type of service is improved, it will affect the increase in the passengers' satisfaction.

The third type of service that becomes a priority for improvement and performance improvement is that the officers understand the passengers' needs individually. The performance of this type of service is still considered not optimal because it still has a specific gap with the passengers' expectations. In addition, this type of service is also considered to have a considerable influence on the increase in the level of the passengers' satisfaction if its performance runs optimally. The passengers expect to meet their needs, but the performance shown by operational and airport management employees regarding this type of service is still far from the passengers' expectations. Therefore, it is highly expected that the improvements to this type of service will be able to keep up with the passengers' expectations. Further, this type of service is also included in the one dimensional (O) category so that its performance is still possible because it will affect the increase in the passengers' satisfaction. 
Table 5. Priority service

\begin{tabular}{|c|c|c|c|c|c|}
\hline \multirow{2}{*}{ Types of Services } & \multirow{2}{*}{$\begin{array}{c}\text { Servqual Method } \\
\text { (Service Gap Score) }\end{array}$} & \multicolumn{2}{|c|}{ Kano Model } & \multirow{2}{*}{$\begin{array}{l}\text { Coefficient } \\
\text { of Priority }\end{array}$} & \multirow{2}{*}{$\begin{array}{l}\text { Number of } \\
\text { Priority }\end{array}$} \\
\hline & & EOS & EOD & & \\
\hline $\begin{array}{l}\text { The airport employees give personal } \\
\text { attention to every passenger }\end{array}$ & -1.0435 & 0.5383 & -0.5561 & 2.1379 & 1 \\
\hline $\begin{array}{l}\text { The airport has an atractive waiting } \\
\text { room }\end{array}$ & -1.1175 & 0.5808 & -0.4192 & 2.1175 & 2 \\
\hline $\begin{array}{l}\text { The airport employees understand } \\
\text { passengers need specifically }\end{array}$ & -0.9800 & 0.5075 & -0.5955 & 2.0830 & 3 \\
\hline The airport employees offer fast service & -0.9125 & 0.4724 & -0.6784 & 2.0633 & 4 \\
\hline The airport employees serve fairly & -0.8925 & 0.3602 & -0.7909 & 2.0436 & 5 \\
\hline $\begin{array}{l}\text { The airport employees apologised when } \\
\text { making a mistake }\end{array}$ & -0.8150 & 0.4246 & -0.7739 & 2.0135 & 6 \\
\hline $\begin{array}{l}\text { Passengers trust to the airport } \\
\text { employees }\end{array}$ & -0.8350 & 0.4372 & -0.7412 & 2.0134 & 7 \\
\hline The service process run on time & -0.8875 & 0.3442 & -0.7739 & 2.0056 & 8 \\
\hline $\begin{array}{l}\text { The airport employees provide } \\
\text { information accurately }\end{array}$ & -0.8250 & 0.3266 & -0.8141 & 1.9657 & 9 \\
\hline $\begin{array}{l}\text { Passengers complaints are handled } \\
\text { quickly }\end{array}$ & -0.8600 & 0.3367 & -0.7337 & 1.9304 & 10 \\
\hline $\begin{array}{l}\text { The airport employees are ready when } \\
\text { needed }\end{array}$ & -0.8075 & 0.3703 & -0.738 & 1.9158 & 11 \\
\hline $\begin{array}{l}\text { Passengers feel safe in their } \\
\text { transactions with the airport employees }\end{array}$ & -0.7300 & 0.4046 & -0.7659 & 1.9005 & 12 \\
\hline $\begin{array}{l}\text { The airport employees are polite to } \\
\text { passengers consistently }\end{array}$ & -0.7875 & 0.3627 & -0.7456 & 1.8958 & 13 \\
\hline The airport has up-to-date equipments & -0.9900 & 0.3894 & -0.5101 & 1.8895 & 14 \\
\hline $\begin{array}{l}\text { Sevice is carried out proprely since first } \\
\text { time }\end{array}$ & -0.7550 & 0.3275 & -0.806 & 1.8885 & 15 \\
\hline $\begin{array}{l}\text { The airport employees are well dressed } \\
\text { and appear neat }\end{array}$ & -0.7725 & 0.4106 & -0.7053 & 1.8884 & 16 \\
\hline $\begin{array}{l}\text { The airport employees inform service } \\
\text { quickly }\end{array}$ & -0.7625 & 0.3965 & -0.7121 & 1.8711 & 17 \\
\hline The airport looks clean & -0.8950 & 0.3452 & -0.627 & 1.8672 & 18 \\
\hline The airport employees serve seriously & -0.6675 & 0.3367 & -0.7772 & 1.7814 & 19 \\
\hline $\begin{array}{l}\text { The airport employees have the } \\
\text { competence to do their job }\end{array}$ & -0.7450 & 0.2814 & -0.7487 & 1.7752 & 20 \\
\hline
\end{tabular}




\section{6}

\section{CONCLUSIONS}

Based on the results of the data analysis that has been done, the findings are as follows:

1. The service quality at Yogyakarta Adisucipto Airport is still not in line with the passengers' expectations. It is evidenced from the results of data analysis using the Servqual method, nevertheless, find a significant gap between the quality of service expected by the passengers, and the quality of service that is received by the passengers. Services that are received by the passengers have lower performance than the expected service.

2. The results of the integration of the Servqual method and the Kano model show that there are three types of services that become the top priority in improving and developing the performance to increase the service quality at Yogyakarta Adisutjipto Airport. The three types of services are the personal attention to the passengers, the attractive waiting rooms, and the understanding of the passengers' needs individually. The selection of these three types of services is based on consideration of the service gap values, the extent of satisfaction, and the extent of dissatisfaction. The determination of the three types of services is based on the Kano category of the three types of services that are included in one dimensional and attractive categories, which is possible the passengers' satisfaction if the performance in the service category within the Kano category is improved.

\section{REFERENCES}

Al-alak, B. A., Salih, A. and Alnaser, M. (2012) 'Assessing the Relationship Between Higher Education Service Quality Dimensions and Student Satisfaction Professor of marketing College Of Business Management and Accounting Department', Australian Journal of Basic and Applied Sciences, 6(1), pp. 156-164.

Bezerra, G. C. L. and Gomes, C. F. (2016) 'Measuring airport service quality: A multidimensional approach', Journal of Air Transport Management. Elsevier Ltd, 53, pp. 8593. doi: 10.1016/j.jairtraman.2016.02.001.

Darus, M. D. (2015) 'Analisis Tingkat Kepuasan Penumpang Terhadap Kualitas Pelayanan Di Bandar Udara Internasional Kualanamu', Jurnal Ekonomi dan Keuangan, 3(6), pp. 408-420.

Gronlund, N. E. (1990) Measurement and Evaluation in Teaching. 6th edn. New York: Macmillan Publishing.

Herbowo, A. (2018) Analisis Kualitas Pelayanan dengan Pendekatan Model Kano Pada Bank XYZ. Universitas Gadjah Mada Yogyakarta.

Horonjeff, et al. (2010) Planning and Design of Airports. fifth. Mc. Graw-Hill Inc.

Innayah, L. I. (2017) Analisis Desain Antrian Penumpang Keberangkatan di Terminal A Bandar Udara Adisutjipto Yogyakarta. Universitas Gadjah Mada Yogyakarta.

Kano, N. S. (1984) 'Attractive Quality and Mustbe Quality', The Journal of the Japanese Society for Quality Control, April, pp. 39-48.

Kurniawan, R. (2017) 'Passengers' Perspective Toward Airport Service Quality (ASQ) (Case Study at Soekarno-Hatta International Airport)', Journal of the Civil Engineering Forum, 3(1), p. 291. doi: 10.22146/jcef.26547.

Ma, M. Y., Chen, C. W. and Chang, Y. M. (2019) 'Using Kano model to differentiate between future vehicle-driving services', International Journal of Industrial Ergonomics. Elsevier, 69(December 2018), pp. 142-152. doi: 10.1016/j.ergon.2018.11.003.

Muda, Y. N. T. (2014) Tinjauan Teknis Pelayanan Bandar Udara Frans Seda Maumere. Universitas Atma Jaya Yogyakarta.

Pabedinskaitè, A. and Akstinaitè, V. (2014) 'Evaluation of the Airport Service Quality', Procedia - Social and Behavioral Sciences, 110, pp. 398-409. doi: 10.1016/j.sbspro.2013.12.884.

Parasuraman, A., Zeithaml, V., Berry, L. (1988) 'SERVQUAL: A Multiple-Item Scale for Measuring Consumer Perceptions of Service 
Quality', Jorunal of Retailing, 64(September 2014), pp. 12-40. doi: 10.1016/S01482963(99)00084-3.

Parasuraman, A., Zeithaml, V. A. and Berry, L. L. (1985) 'A Conceptual Model Service Its Quality and Implications for Future Research', Research Paper, 49(4), pp. 41-50. doi: 10.1016/S01482963(99)00084-3.

PT. Angkasa Pura I (2017) Total Pergerakan Lalu Lintas Angkutan Udara PT. Persero Angkasa Pura I. Yogyakarta.

PT. Angkasa Pura I (2018) Total Pergerakan Lalu Lintas Angkutan Udara PT. Persero Angkasa Pura I.

Santosa, D. D. K. (2007) Analisis Kepuasan Konsumen Terhadap Fasilitas Ruang Tunggu Terminal Bandara Adisutjipto. Universitas Sanata Dharma Yogyakarta.

Sartono, Wardani. Dewanti. Rahman, T. (2016) Bandar Udara: Pengenalan dan Perancangan Geometrik Runway, Taxiway, dan Apron. 1st edn. Yogyakarta: Gadjah Mada University Press.

Setiawan, E. (2018) Analisis Kualitas Layanan Rumah Sakit Ibu dan Anak Ananda Kota Lubuklinggau Menggunakan Metode Servqual. Universitas Gadjah Mada Yogyakarta.
Sri Mulyani dan Dwi Hartini (2016) 'Kajian Tingkat Pelayanan Penumpang di Bandara Adisutjipto Yogyakarta', Jurnal AngkasaAngkasa, VIII(1), pp. 147-158.

Subekti, S. (2018) 'Kepuasan Penumpang Terhadap Pelayanan Terminal Domestik di Bandar Udara Adi Sucipto Yogyakarta', Warta Penelitian Perhubungan, 29(2), p. 277. doi: 10.25104/warlit.v29i2.558.

Subri, M. (2003) Ekonomi Sumber Daya Manusia. Jakarta: Raja Grafindo Persada.

Sugianto, D. (2019) Kapasitas Bandara Kulon Progo 8 Kali Lipat Bandara Adisutjipto, Detik.com.

Yao, M. L., Chuang, M. C. and Hsu, C. C. (2018) 'The Kano model analysis of features for mobile security applications', Computers and Security. Elsevier Ltd, 78(2018), pp. 336-346. doi: 10.1016/j.cose.2018.07.008.

Yousapronpaiboon, K. (2014) 'SERVQUAL: Measuring Higher Education Service Quality in Thailand', Procedia - Social and Behavioral Sciences. Elsevier B.V., 116, pp. 1088-1095. doi: 10.1016/j.sbspro.2014.01.350.

Zeithaml, V. A., Berry, L. L. and Parasuraman, A. (2006) 'The Behavioral Consequences of Service Quality', Journal of Marketing, 60(2), p. 31. doi: $10.2307 / 1251929$. 
[This page is intentionally left blank] 